\title{
EGFR/HER2 Inhibitor AV-412
}

National Cancer Institute

\section{Source}

National Cancer Institute. EGFR/HER2 Inhibitor AV-412. NCI Thesaurus. Code C64627.

A second-generation, orally bioavailable dual kinase inhibitor with potential antineoplastic activity. EGFR/HER2 inhibitor AV-412 binds to and inhibits the epidermal growth factor receptor (EGFR) and the human epidermal growth factor receptor 2 (HER2), which may result in the inhibition of tumor growth and ang iogenesis, and tumor regression in EGFR/HER2-expressing tumors. This agent may be active against EGFR/HER2expressing tumor cells that are resistant to first-generation kinase inhibitors. EGFR and HER2 are receptor tyrosine kinases that play major roles in tumor cell proliferation and tumor vascularization. 